DOI

\title{
ОСОБЛИВОСТІ ПРОСТОРОВОї І СТРУКТУРНОЇ ОРГАНІЗАЦІї ШЛУНКА БІЛИХ ЛАБОРАТОРНИХ ЩУРІВ У НОРМІ
}

\section{ДВНЗ «Тернопільський державний медичний університет імені І. Я. Горбачевського МОз України»}

\begin{abstract}
РЕЗЮМЕ. Дослідження проведено на 12 інтактних білих лабораторних щурах. Макрометрично вимірювали довжину, ширинуітовщинушлунказнаступнимобчисленнямйогооб'єму. Длягістологічногодослідження забирали шматочки тканин із різних відділів шлунка. Морфометричні дослідження включали визначення товщини слизової, м'язової, серозної оболонок та підслизової основи, площі епітеліоцитів, діаметра ядер епітеліоцитів, ядерноцитоплазматичних співвідношень (ЯЦС). Середні розміри шлунка у інтактних тварин: довжина - $(3,93 \pm 0,13)$ см, ширина - $(2,20 \pm 0,09)$ см, товщина - $(1,45 \pm 0,08)$ см, об'єм шлунка у середньому складає $(6,72 \pm 0,81)$ см $^{3}$. Найбільший питомий об'єм має дно шлунка. При зовнішньому макроскопічному огляді дно шлунка за його білуватим забарвленням легко можна відрізнити від червоно-сіруватих тіла та пілоричної частини. Ще чіткіше дно шлунка можна віддиференціювати при візуальному огляді його слизової оболонки:слизова оболонка дна відмежована від тіла шлунка чіткою дугоподібною складкою або складчастим краєм. При гістологічному дослідженні складчастого краю встановлено, що його основу складає дуплікатра підслизової основи, яка зі сторони дна шлунка покрита багатошаровим плоским епітелієм, а зі сторони тіла - залозистим епітелієм. Морфометричні дослідження стінки шлунка інтактних білих лабораторних щурів дозволили встановити наступні кількісні параметри ії структурних компонентів. Товщина серозної оболонки у середньому складала $(7,83 \pm 0,31)$ мкм, м'язової $-(40,17 \pm 0,75)$ мкм, підслизової- $(24,00 \pm 0,78)$ мкм і слизової- $(96,00 \pm 0,97)$ мкм. Площа ядер гладком'язових клітин (ГМК) дещо більша, ніж площа ядер залозистого епітелію, водночас питомий об'єм цитоплазми у ГМК, навпаки, менший. Відповідно до цього і показник ЯЦС у ГМК вищий, ніж у епітеліоцитів слизової.

КЛючОВІ СлОВА: шлунок щура, будова, морфометрія.
\end{abstract}

Вступ. Одним із ефективних методів вивчення закономірностей розвитку патоморфогенетичних змін, що виникають при різноманітних захворюваннях, $\epsilon$ їх експериментальне відтворення на тваринах [1-3]. При цьому основне завдання експериментального моделювання полягає у тому, щоб на основі проведення аналогії з нормою отримати необхідні дані про особливості перебігу даного патологічного процесу $[4,5]$.

Подібність структурної організації органів та тканин людини і деяких тварин обумовлює використання останніх для експериментального моделювання різноманітних захворювань, що зустрічаються у клінічній практиці $[3,6,7]$. Разом з тим, для глибшого розуміння і адекватної інтерпретації результатів експерименту та розробки методів їх корекції слід враховувати певні видові особливості та відмінності, які $є$ характерними для тварин конкретного виду, а також брати за основу для порівняння кількісні параметри їх тканин, органів і систем.

Анатомія шлунка лабораторних щурів в літературі описана ще досить мало, а наявні окремі дані не $\epsilon$ систематизованими [8], тоді як відомо, що форма, будова і топографія шлунка у хребетних тварин варіюють у значній мірі $[9,10]$.

Мета роботи. Дати комплексну описову макро-, мікроскопічну та кількісну характеристику будови шлунка білих лабораторних щурів.
Матеріал і методи досліджень. Для проведення дослідження використано шлунки 12 інтактних білих лабораторних щурів-самців з масою тіла 180,0-200,0 г.

Макрометрично вимірювали довжину, ширину і товщину шлунка з наступним обчисленням його об'єму за формулою $[11,12]$ :

$V=a \times b \times c \times 0,523$

де 0,523 - коефіцієнт, отриманий за даними ехопланометрії;

$a-$ довжина (см),

$b$ - ширина (см),

с-товщина (см).

Для гістологічного дослідження шматочки тканин із різних відділів шлунка фіксували в 10 \%-му розчині нейтрального формаліну, рідині Карнуа і в $96^{\circ}$ спирті. Гістологічні зрізи забарвлювали гематоксиліном і еозином, резорцинфуксином за Вейгертом.

Морфометричні дослідження включали визначення: товщини слизової, м'язової, серозної оболонок та підслизової основи, підслизовослизовий, підслизово-м'язовий, м'язово-слизовий індекси, площу епітеліоцитів, діаметр ядер епітеліоцитів, ядерно-цитоплазматичні співвідношення (ЯЦС).

Статистичну обробку отриманих результатів здійснювали методом варіаційної статистики 3 використанням програми «Microsoft Excel». Визначали середнє значення (M), стандартне відхи- 
Огляди літератури, оригінальні дослідження, погляд на проблему

лення (ठ) та похибку середнього (m). Статистичний аналіз результатів дослідження проводили з використанням «Microsoft® Office Exel 2003».

Усі експериментальні дослідження проводилися з дотриманням «Правил проведення робіт з використанням експериментальних тварин».

Результати й обговорення. Топографічно шлунок білого лабораторного щура розташований у передньому відділі його черевної порожнини безпосередньо позаду від печінки і дещо лівіше від серединної лінії. У ньому розрізняють дві поверхні і велику та малу кривини, а також дно, тіло і пілоричну частини. Форма шлунка у тварин даного виду наближена до гачкуватої, причому найбільший питомий об'єм займає дно, яке розта-

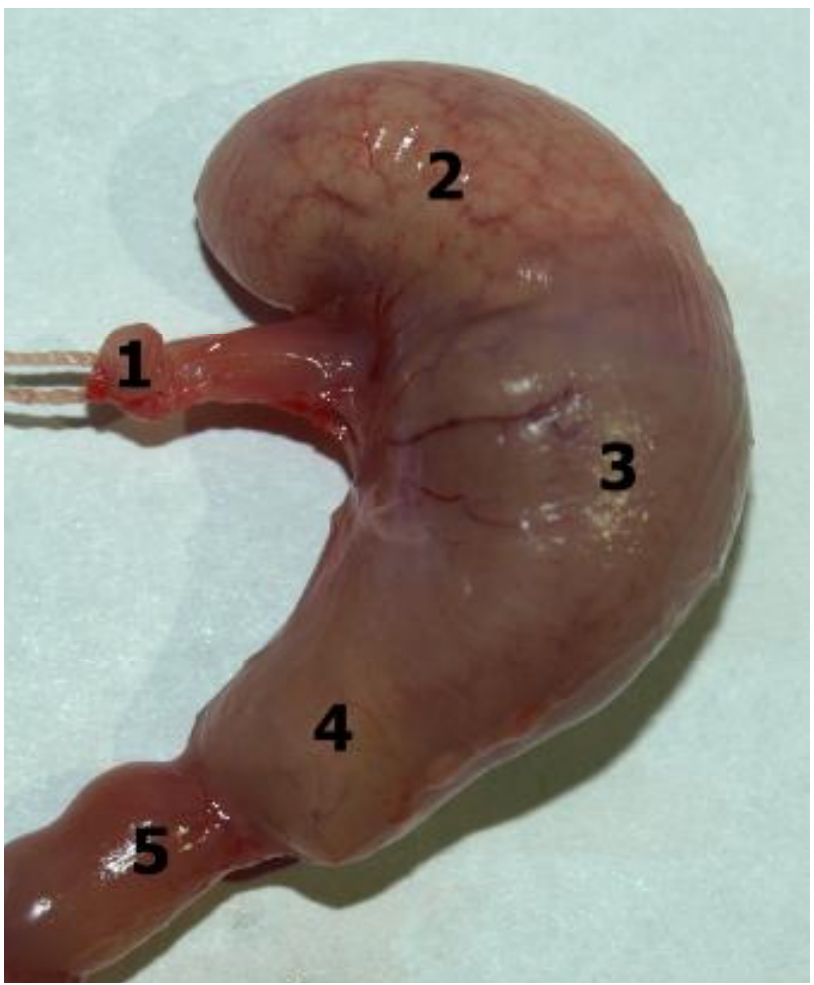

Рис. 1. Макропрепарат шлунка інтактного щура.

Стравохід - 1, дно шлунка - 2, тіло шлунка - 3, пілорична частина шлунка - 4, дванадцятипала кишка -5.

Середні розміри шлунка у інтактних тварин наступні: довжина - $(3,93 \pm 0,13)$ см, ширина $(2,20 \pm 0,09)$ см, товщина - $(1,45 \pm 0,08)$ см. Відповідно до цього об'єм шлунка у середньому складає $(6,72 \pm 0,81) \mathrm{cm}^{3}$.

При гістологічному дослідженні стінки шлунка щура в ділянці складчастого краю досить чітко видно, що основу цього краю складає сполучнотканинний прошарок із дуплікатри підслизової оболонки, яка зі сторони дна шлунка покрита багатошаровим плоским епітелієм без залозис- шоване лівіше від місця впадання стравоходу по малій кривині. Навіть при зовнішньому макроскопічному огляді легко можна відрізнити дно шлунка за його білуватим забарвленням, на відміну від червоно-сіруватих тіла та пілоричної частини (рис. 1). Ще чіткіше дно шлунка можна віддиференціювати при візуальному огляді його слизової оболонки. Слизова оболонка дна відрізняється не тільки світлішим забарвленням, на відміну від тіла і пілоричної частини, але й відмежована від нього чіткою дугоподібною складкою (рис. 2), а6о, як її ще називають, складчастим краєм. Майже поряд із входом у шлунок розташований і вихід із нього, де бере свій початок дванадцятипала кишка.

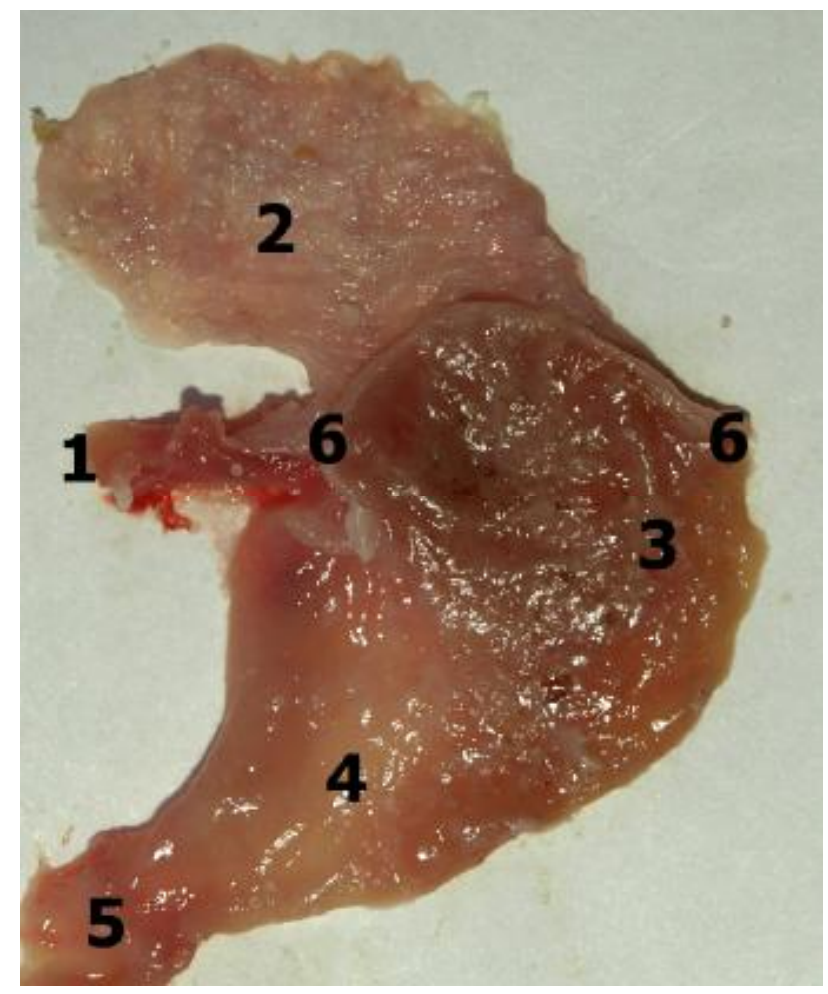

Рис. 2. Макропрепарат рельєфу слизової оболонки шлунка інтактного щура.

Стравохід - 1, дно шлунка - 2, тіло шлунка - 3, пілоричначастинашлунка-4, дванадцятипала кишка-5, перехідна складка слизової (складчастий край) - 6 .

тих структур (через що цю їі частину називають беззалозистою), а та її частина, що покриває тіло і пілоричний відділ - містить травні залози і називається, відповідно, залозистою (рис. 3).

У залозистій частині шлунка слизова оболонка представлена трубчастими залозами, які утворені однорядним циліндричним епітелієм. За рахунок відрогів підслизової основи слизова оболонка утворює складки, між якими розташовані шлункові ямки, у які відкриваються шлункові залози (рис. 4). 


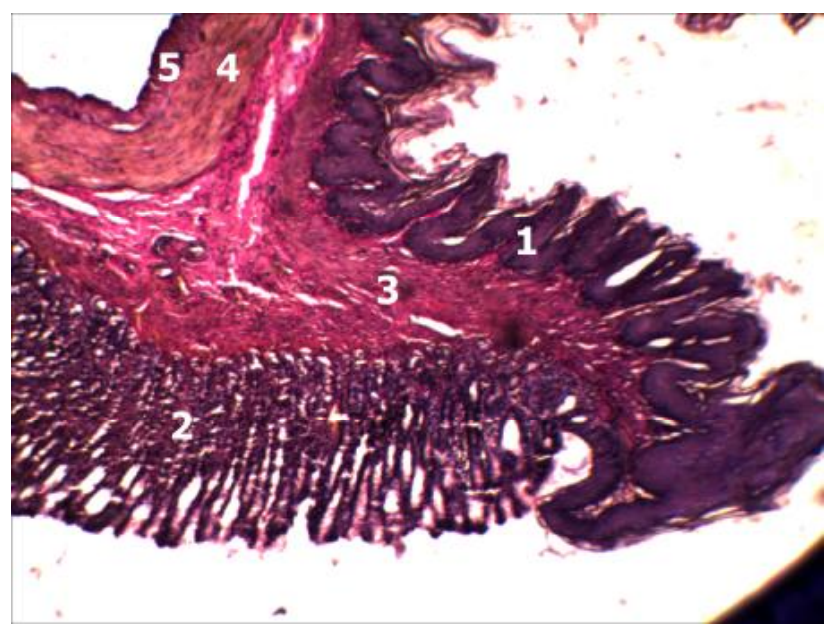

Рис. 3. Гістологічний зріз стінки шлунка інтактного щура. Забарвлення гематоксиліном і еозином. $x 180$.

Беззалозиста частина слизової оболонки дна шлунка - 1, залозиста частина слизової оболонки тіла шлунка - 2, підслизова основа - 3, м'язова оболонка 4 , серозна оболонка -5 .

Морфометричні дослідження стінки шлунка інтактних білих лабораторних щурів дозволили встановити наступні кількісні параметриії структурних компонентів. Товщина серозної оболонки у середньому складала $(7,83 \pm 0,31)$ мкм, м'язової $(40,17 \pm 0,75)$ мкм, підслизової - $(24,00 \pm 0,78)$ мкм

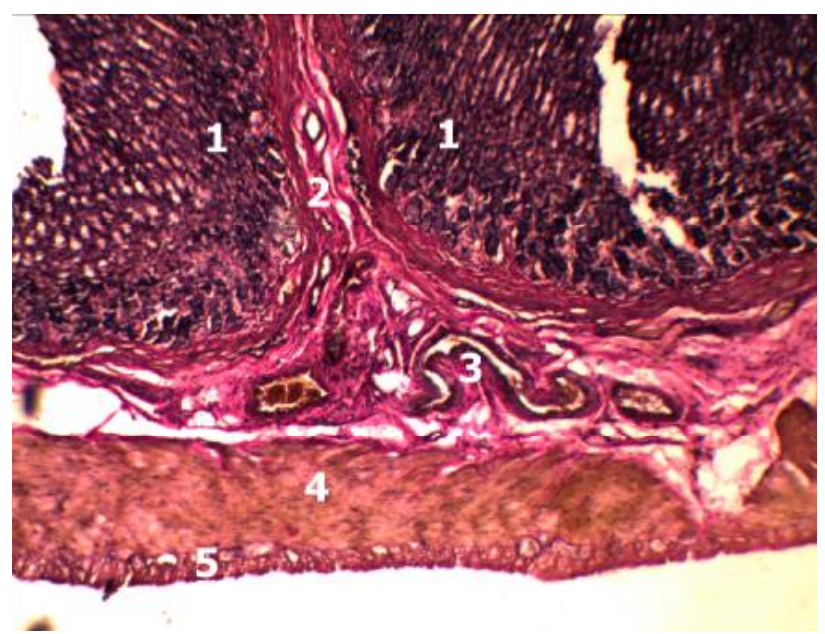

Рис. 4. Гістологічний зріз стінки шлунка інтактного щура. Забарвлення гематоксиліном і еозином. $x 180$.

Трубчасті залози шлунка - 1, відроги підслизової основи - 2, судини підслизової основи - 3, м'язова оболонка - 4, серозна оболонка - 5 .

і слизової - $(96,00 \pm 0,97)$ мкм, а співвідношення між ними відповідно було як: 1,00 / 5,13 / 3,06 / 12,26

Результати вивчення кількісного стану клітинних компонентів оболонок стінки шлунка представлені у таблиці 1.

Таблиця 1. Результати морфометричного дослідження клітинних компонентів оболонок стінки шлунка

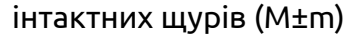

\begin{tabular}{|l|c|c|c|c|}
\hline \multirow{2}{*}{ Оболонка шлунка } & \multicolumn{4}{|c|}{ Параметр } \\
\cline { 2 - 5 } & площа ядра, мкм² & площа клітини, мкм & площа цитоплазми, мкм & ЯЦС, \% \\
\hline $\begin{array}{l}\text { Епітеліоцити } \\
\text { слизової оболонки }\end{array}$ & $7,56 \pm 0,22$ & $61,50 \pm 0,87$ & $53,94 \pm 0,69$ & $14,21 \pm 0,27$ \\
\hline $\begin{array}{l}\text { ГМК м'язової обо- } \\
\text { лонки }\end{array}$ & $8,56 \pm 0,23$ & $56,87 \pm 0,93$ & $48,31 \pm 0,81$ & $17,73 \pm 0,44$ \\
\hline
\end{tabular}

Як видно із таблиці, площа ядер гладком'язових клітин (ГМК) дещо більша, ніж площа ядер залозистого епітелію, водночас питомий об'єм цитоплазми у ГМК, навпаки, менший. Відповідно до цього і показник ЯЦС у ГМК вищий, ніж у епітеліоцитів слизової. Такі відмінності можуть бути обумовлені як формою клітин (веретеноподібною у ГМК і циліндричною у епітеліоцитів), так і особливостями їх функціонального призначення.

Підсумовуючи можна сказати, що, маючи багато спільного у будові із шлунком людини, шлунок щурів має певні особливості структурної організації. Зокрема це низьке впадання стравоходу по малій кривині, відмінності у гістологічній будові слизової оболонки різних відділів і наявність чіткої межі між ними.
Слід також взяти до уваги кількісні показники структурної організації оболонок стінки шлунка та їх клітинних компонентів, які можуть складати основу для порівняння при моделюванні патологічних процесів і об'єктивної оцінки ступеня патологічних змін.

Висновок. За структурною організацією шлунок білих лабораторних щурів близький до шлунка людини, однак має певні видові особливості, які слід враховувати при проведенні експериментальних досліджень:

- топографічні - внаслідок горизонтального розташування тіла;

- просторові - низьке впадання стравоходу;

- гістологічні - різна будова слизової оболонки: беззалозиста в ділянці дна і залозиста в ділянці тіла шлунка. 
Огляди літератури, оригінальні дослідження, погляд на проблему

Перспективи подальших досліджень. Подальші дослідження дозволять дати якісну і кількіс-

ну оцінку ступеня змін у тканинах шлунка щурів при моделюванні різноманітних патологічних процесів.

\section{ЛITEPATУРA}

1. Давыдовский И. В. Проблема причинности в медицине (этиология) / И. В. Давыдовский. - М. : Медгиз, 1962. - С. 137-140.

2. Саркисов Д. С. Структурные основы адаптации и компенсации нарушенных функций / Д. С. Саркисов. М. : Медицина, 1997. - 448 с.

3. Animal Models in Eye Research / A. Gwon, A. Panagiotis, I. M. Tsonis [et al.] // Academic Press. - 2007. № 4. - P. 184-187.

4. Зиновьев А. А. Логическая модель как средство научного исследования / А. А. Зиновьев, И. И. Ревзин // Вопросы философии. - 1960. - № 1. - С. 82-90.

5. Фролов И. Т. Гносеологические проблемы моделирования биологических систем / И. Т. Фролов // Вопросы философии. - 1981. - № 2. - С. 39-51.

6. Шляховер В. Е. Количественная характеристика структурной организации миокарда собаки / В. Е. Шляховер, Н. И. Яблучанский, В. И. Шевченко // Кровообращение. - 1983. - Т. 16, № 2. - С. 3-6.

7. Schaper G. Ultrastructural morhometric analysis of myocardium from dogs, rats, hamsters, mice and from human hearts / G. Schaper, E. Meiser, G. Stammler // Circ. Res. - 1985. - Vol. 56, № 3. - P. 377-391.

8. Петренко В. М. Форма и топография желудка у белой крысы / В. М. Петренко // Успехи современного естествознания. - 2012. - № 4. - С. 227-229.

9. Ромер А. Анатомия позвоночных ; пер. с англ. яз. / А. Ромер, Т. Парсонс. - М. : Изд-во «Мир», 1992. T. 2. $-406 \mathrm{c}$.

10. Шмальгаузен И. И. Основы сравнительной анатомии позвоночных животных. -3-е изд-е./ И. И. Шмальгаузен.-М. :Госуд. учеб.-пед. изд-во наркомпроса РСФСР, 1938. -488 c.

11. Гриценко С. І. Спосіб вимірювання об'єму біологічних об'єктів / С. І. Гриценко, О. О. Вільцанюк // Вісник морфології. - 2000. - № 2. - С. 333-334.

12. Hricak H. Sonographic determination of renal volume / H. Hricak, R. P. Lieto // Radiology. - 2000. - Vol. 183. P. 311-312.

\section{FEATURES AND SPATIAL STRUCTURE ORGANIZATION STOMACH OF WHITE LABORATORY RATS IN NORM}

๑O. A. Bedenyuk

\section{SHEI «Ternopil State Medical University by I. Ya. Horbachevsky of MPH of Ukraine»}

SUMMARY. The research was conducted on 12 intact and white laboratory rats. The length, width and thickness of the stomach were measured macrometrically, before calculating its volume. For histological examination of tissue slices taken from different parts of the stomach. Morphometric study included determination: thick mucous, muscular, serous membranes and submucosa, area of epithelial cells, the diameter of nuclei, nuclear-cytoplasmic ratio (NCR). The average size of the stomach in intact animals: length $-(3,93 \pm 0,13) \mathrm{cm}$, width $-(2,20 \pm 0,09) \mathrm{cm}$, thickness $-(1,45 \pm 0,08) \mathrm{cm}$, volume of the stomach on average $(6,72 \pm 0,81) \mathrm{cm}^{3}$. The highest specific volume covers the bottom of the stomach. The external macroscopic examination can easily distinguish whitish bottom colour of his stomach from reddish-grey body and pyloric parts. Even more clearly the bottom of the stomach can be differentiated by visual inspection of its mucosa, the mucous membrane of the bottom of the body of the stomach is separated by distinct arched line or plaited edge. While histological study of this plaited edge was established that its basis is duplikatra submucosa, which from the stomach bottom is covered by stratified squamous epithelium, but from the side of the body side - glandular epithelium. Morphometric study of the stomach wall intact where laboratory rats revealed the following quantitative parameters of structural components. Serous membrane thickness average was $(7,83 \pm 0,31) \mathrm{mm}$, muscular $-(40,17 \pm 0,75) \mathrm{mm}$, submucosal $-(24,00 \pm 0,78) \mathrm{mm}$ and mucus $-(96,00 \pm 0,97) \mathrm{mm}$. Area nuclei of smooth muscle cells (SMC) is slightly larger than the area of the nuclei of glandular epithelium, while the specific volume of the cytoplasm in SMC is inversely lower. According to this rate, NCR in SMC is higher than in the epithelial mucosa.

KEY WORDS: rat stomach, structure, morphometry. 